\title{
GREEN ROOFS AS AN ALTERNATIVE SOLUTION TO REDUCED GREEN SURFACE AREA IN HIGHLY URBANIZED CITIES OF THE EUROPEAN UNION - THE STUDY CASE OF THE NETHERLANDS
}

\author{
Agnieszka Boas Berg', Maja Radziemska², Dana Adamcová3, \\ Magdalena Daria Vaverková3 ${ }^{凶}$ \\ 'Shada BV, Apeldoorn \\ ${ }^{2}$ Department of Environmental Improvement, Warsaw University of Life Sciences - SGGW, Warsaw \\ ${ }^{3}$ Faculty of AgriSciences, Mendel University in Brno, Brno
}

\begin{abstract}
The authors presented information on green roofs in the European Union (EU) based on the experience of construction companies in the Netherlands and Poland. The choice of these countries was related to the fact that Dutch land planners are interested in cooperating and sharing their experience with Polish specialists. The article also presents a brief history of the use of green roofs. The technical knowledge (on construction, the design of specialized covers and preparation of the entire system) have been gathered from Dutch companies specializing in plant breeding on green roofs. The authors described the advantages of green roofs and the just cause of financing these projects by the EU. Green roofs relieve some of the load on the sewage systems in cities by absorbing precipitation water. They help preventing the floods after storms and torrents. They reduce the negative consequences of heat islands effect and decrease $\mathrm{CO}_{2}$ emission. Green roofs can solve problems in the areas of Poland that are exposed to harmful gases. Furthermore, green roofs act as a thermal insulation, thus less energy for winter heating and summer air conditioning (energy efficiency) is being used.
\end{abstract}

Key words: green roofs history, green roofs, green areas in the cities, architecture, garden roofs, green roofs examples

\section{INTRODUCTION}

The European Union (EU) should meet the expectations of a modern European society in terms of living standards, openness, transparency and commitment, and should also function more effectively and be able to cope with the global challenges of the modern world, such as climate change, reduction of green areas, deforestation and floods. Climate change, urbanization, noise and air quality issues are the main problems that need to be solved (Adger, Barnett, Brown \& Marsh, 2013; Petrović, Bojović \& Petrović, 2016; Shaneyfelt, Anderson, Kumar \& Hunt, 2017).

Green roofs, living walls and green coverings can become an answer to these issues. Climate change and man-made changes in European cities affect the biological balance between plants, animals and humans (Baryła, Siedlicka \& Karczmarczyk, 2015). An example of impaired balance is a reduced amount of bees in cities and municipalities. Honeybees play an important role in the conservation of natural ecosystems because they help

\footnotetext{
$\otimes_{\text {magda.vaverkova@uake.cz }}$ 
in pollinating a diverse range of crops, fruits, and plants (Klein et al., 2007; Bradbear, 2009; Gwak, Lee, Lee $\&$ Sohn, 2017). Nevertheless, the population of honeybees is gradually decreasing globally because of diverse reasons such as expansion of urban areas, use of pesticides for agriculture, climate change, and competition from non-native species (Kluser \& Peduzzi, 2007; Gwak et al., 2017). In particular, honeybee habitats in urban areas have sharply declined due to urban sprawl (Murray, Kuhlmann \& Potts, 2009; Winfree, Aguilar, Vázquez, LeBuhn \& Aizen, 2009; Grixti, Wong, Cameron \& Favret, 2009; Gwak et al., 2017). However, honeybees foraging activities are also an important part of food production and ecosystems in urban areas (Quistberg, Bichier \& Philpott, 2016; Gwak et al., 2017). In such a scenario, green roofs have received attention as an ecological engineering technique to increase green coverage in urban areas (Tonietto, Fant, Ascher, Ellis \& Larkin, 2011; Mitsch, 2012; MacIvor \& Ksiazek, 2015; Gwak et al., 2017).

The Netherlands, one of the Benelux countries, is a rich country but one of the most densely populated in the world. The area of the Netherlands is $41,543 \mathrm{~km}^{2}$. The country is inhabited by 17.1 million people (data from 2017). The density of population is 413 people per $\mathrm{km}^{2}$. With such a high density of population ratio, in order to maintain a balance in the natural environment both politicians, environmentalists and the public must agree (www.amsterdam.nl/actueel).

An example of reaching a middle ground between investors and environmentalists is the Delta Plan - the system of water dams in the Netherlands (Francesch-Huidobro, Dabrowski, Tai, Chan \& Stead, 2017). The Delta Plan is a successful compromise between environmentalists, farmers, fishermen and the industrial lobby. Dams do not interfere with the movement of vessels going to Euro port in Rotterdam. The natural environment of the various animal species has also been preserved. The dams are constructed in a special way, they are not closed to the bottom of the sea, and sea water is still flowing between the sea and the part closed by the dam. Fish, marine crustaceans, algae - all fauna and flora have a chance of moving between the sea and the bays (www.rotterdam.nl).

The ecosystem is not disturbed and the dams function properly because they are only being completely closed to hazards such as high, stormy waves and strong winds. In the Netherlands, dialogue and problem solving are a matter of agreement and appointing a representative from one another to monitor compliance with environmental and flood protection arrangements. Caring for the environment and segregation of waste instead of storing it results from high social awareness and relevant financial, administrative and legal instruments. However, the Dutch did not always take care of the environment. At the turn of the century they cut out almost all the forests in their country - the wood was needed to build masts for the great Dutch fleet. In fact, the larger forest area remained in Gelderland - especially the area surrounding the Apeldoorn municipality (Yousefpour et al., 2015). Nowadays, forests, nature and land in the Netherlands are under the special care of the state. Land property in the Netherlands is one of the most expensive in the EU, but pragmatic Dutch municipal authorities try to encourage residents to use green solutions, like creating green roofs. There are subsidies for this kind of investment. Many of Dutch municipalities offer subsidies up to $50 \%$ for building green roofs. The other EU countries can also apply for financial aid to create green roofs that are important in the drainage and management of precipitation and are part of the flood control system - e.g. in North Rhine - Westphalia the state co-finances this type of construction (Rataj, 2016). Copenhagen is the first Scandinavian city where all new buildings with roofs with the rake angle less than $30^{\circ}$ have green roofs. This rule was first applied in 2010 to reduce $\mathrm{CO}_{2}$ emission by 2025 (Locatelli et al., 2014). There are eco-friendly directives that encourage residents to build green roofs also in Germany (Berardi, Hoseini, Ghaffarian \& Hoseini, 2014). In many municipalities, the green roof owners receive a discount in the fees for the discharge of rainwater. This is due to the possibility of water retention through the green roof and relieve the drainage system during sudden precipitation. In the case of newly erected buildings with roofs covered with greenery, tax is reduced, for pro-ecological action (Sokołowska \& Krajczyński, 2004). 
Boas Berg, A., Radziemska, M., Adamcová, D., Vaverková, M.D. (2017). Green roofs as an alternative solution to reduced green surface area in highly urbanized cities of the European Union - the study case of the Netherlands. Acta Sci. Pol. Architectura, 16 (4), 59-70. doi: 10.22630/ASPA.2017.16.4.06.

\section{MATERIAL AND METHODS}

The authors compared cities in the Netherlands and Poland in terms of the type and frequency of use of green roofs. The objects were chosen by the authors because they seemed interesting in a given country. The involvement of municipalities in attracting residents to ecology, greening of urbanized areas and the construction of green roofs and roof structures (subsidies, tax credits) were also compared.

\section{HISTORY OF GREEN ROOFS}

Planting vegetation at the building roof top is an old technique. The most famous ancient green roofs were the Hanging Gardens of Babylon constructed around BC 500 (Vijayaraghavan, 2016). It was installed on the roof of a sturdy building supported by masonry columns and arched beams. The roof slab was waterproofed by layers of reed in combination with tar (Jim, 2017). The house design and living style in Roman times are denoted by well-preserved archaeological remains of Pompeii, which was swiftly buried by hot volcanic ashes from the sudden eruption of Vesuvius in AD 79. The wealthy citizens installed green roofs on the flat terraces of their sumptuous villas (Condello, 2014). The open-air and vegetated spaces provided natural extensions of living quarters. A roof garden was also discovered around an audience hall in Roman-Byzantine Caesarea - a Roman colony near the present Haifa city in Israel (Jim, 2017). In the old Egyptian city of al-Fustât (now part of Cairo) founded in AD 641, a Persian visitor in the early eleventh century witnessed a 14-story building equipped with a roof garden irrigated by ox-drawn water wheels (Behrens-Abouseif, 1989). This is a rare written record of green roofs outside Europe and North America. Vikings in the Nordic lands extensively built some old sod roofs since the $11^{\text {th }}$ century. They denoted an expression of environmental determinism by humans dwelling in the harsh Arctic areas with unforgiving weather, and paucity of natural resources especially shortage of wood (Arge, 2000).

In more recent times, peoples tend to cover their rooftops with sod for the purpose of insulation from extreme climates. Modern green roofs, therefore, may acquire their concept from ancient techniques; however technological advances have made modern green roofs far more efficient, practical and beneficial than their ancient counterparts (Vijayaraghavan, 2016).

The adoption of green roofs or living roofs is a growing trend since the 1960s. After gaining popularity in Europe, most of the world is now familiar with this green infrastructure as part of the sustainable design of a building. Green roofs are part of the green infrastructure which uses vegetation, soil, and natural processes to manage water and create healthier urban environments (Semaan \& Pearce, 2016).

German cities started to support green roofs as early as the 1970s (Berardi et al., 2014). For example, in Munich, all suitable flat roofs with a surface area of over $100 \mathrm{~m}^{2}$ have to be 'greened'; the city of Esslingen am Neckar subsidizes $50 \%$ of the costs for green roofs (Brudermann \& Sangkakool, 2017). In Dutch city Copenhagen, green roofs are required for all newly constructed roofs with a pitch of less than $30^{\circ}$ (Berardi et al., 2014). In the Austrian capital Vienna, financial support is granted per $\mathrm{m}^{2}$ of green roof (Brudermann \& Sangkakool, 2017). Chen (2013) reviewed city policies in several Asian and American cities, and found policies and by-laws favoring green roofing in Singapore, Japan, Hong Kong, USA and Canada. Those countries are making a strong initiative to install green roofs during construction of new buildings, and are retrofitting old ones so green roofs can be added in the near future (Vijayaraghavan, 2016). Despite these developments, green roofs remain a niche technology and are, with a few exceptions, not yet widely dispersed in urban European areas (Brudermann \& Sangkakool, 2017). 


\section{GREEN ROOFS IN THE NETHERLANDS}

As mentioned earlier, the Netherlands protect the natural environment and takes action on waste management and flood control. The state and the local governments make it their priority to restore green areas in the cities. The reconstruction of ecosystems and the greening of cities are in the municipal budget programs. This also includes grants for the construction of green roofs. For example, in Apeldoorn, the subsidy is 30 EUR per $\mathrm{m}^{2}$ and the maximum amount requested is 2,500 EUR for individuals and 25,000 EUR for the construction of apartment buildings and businesses (www.apeldoorn.nl).

The maximum subsidy is $50 \%$ of the total roof cost. Some manufacturers of green roofs report on the website that Dutch municipalities use subsidies for investment. Grants for green roofs are used in the following Dutch cities: Alphen aan den Rijn, Almelo, Amsterdam, Amstelveen, Apeldoorn, Capelle aan den IJssel, Den Haag, Groningen, Den Bosch, Leeuwarden, Leiden, Nijmegen, Nieuwegein, Rotterdam, Soest, Utrecht, Tilburg, Zoeterwoude and Zwijndrecht.

Nijmegen is currently involved with housing corporations and companies providing advice and grants to create eco-friendly work spaces. The municipality supports companies and private investors who are interested in building eco-friendly houses with green roofs (https://werkeninnijmegen.nl).

The local authorities put their efforts into creating administrative and financial measures to counter the effects of climate change. Green roofs help absorbing the rainwater and provide cooling and insulation of buildings. The subsidy is $50 \%$ of the green roof cost. Nijmegen is a city in the Netherlands with 170,000 inhabitants that has just won the title of the Green Capital of Europe 2018. This is the title awarded by the European Commission since 2010 to the city, which stands out for economic growth, improving the quality of life and protecting the environment. Nijmegen has applied for this title three times, this year has been a success. Nijmegen is the home city of Paul Goedknegt, the Dutch land planner. He visited Poland this year and presented ecological Dutch solutions (https://werkeninnijmegen.nl).

\section{GREEN ROOFS IN POLAND}

Presently, green roofs appear not only on private properties. They are increasingly being built on public buildings: courts, libraries, universities, office buildings, factories. In Poland up to 2008 built 0.5 million $\mathrm{m}^{2}$ of green roofs annually (Kożuchowski \& Piątek-Kożuchowska, 2009). Nowadays, it can be assumed that this number of investments with green roofs is bigger.

In Poland, green roofs are developing less intensively than in Western Europe. However, some spectacular investments can be seen there. One of the most impressive ones is the roof garden of the Warsaw University Library designed by Irena Bajerska (Fig. 1). Another famous roof garden is located at the Copernicus Science Center, and the Supreme Court Building at Krasińskich Square in Warsaw and Arkadia shopping center (Bartkowicz, 2015). More and more large shopping malls are being designed with green roofs. This is a technique used by large developer companies seeking to encourage customers to buy apartments built in the city center on the roofs of large supermarkets. On the roof of the Sfera II shopping center in Bielsko-Biała (Poland), a housing estate was designed and constructed (Fig. 2). The creator of this concept is architect Ireneusz Hendel. In the inner courtyard of the estate a garden of about $2,000 \mathrm{~m}^{2}$ was built. The roof garden of the shopping mall is only available to residents of this estate. The owners of the apartments have windows with a view to the inner green and the Beskidy Mountains. It is an intensive garden, with a larger cover and large plants and trees. There were trees like; birch, rakes and maples. Among the smaller plants are rose bushes, wild vines and lavender. The garden area is covered with different species of grass. A special irrigation system has also been created - rain water flows into tanks and is used to water the plants (http://bielskobiala. naszemiasto.pl). 
Boas Berg, A., Radziemska, M., Adamcová, D., Vaverková, M.D. (2017). Green roofs as an alternative solution to reduced green surface area in highly urbanized cities of the European Union - the study case of the Netherlands. Acta Sci. Pol. Architectura, 16 (4), 59-70. doi: 10.22630/ASPA.2017.16.4.06.
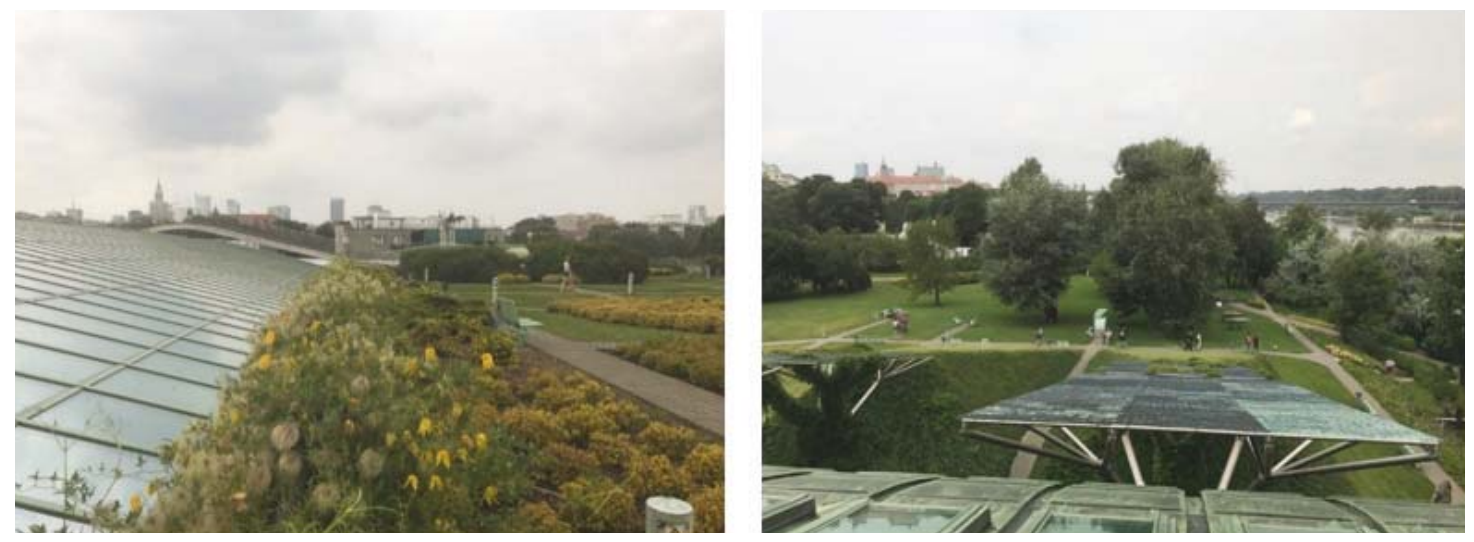

Fig. 1. Warsaw University Library roof garden (photo by M.D. Vaverková, 2017)
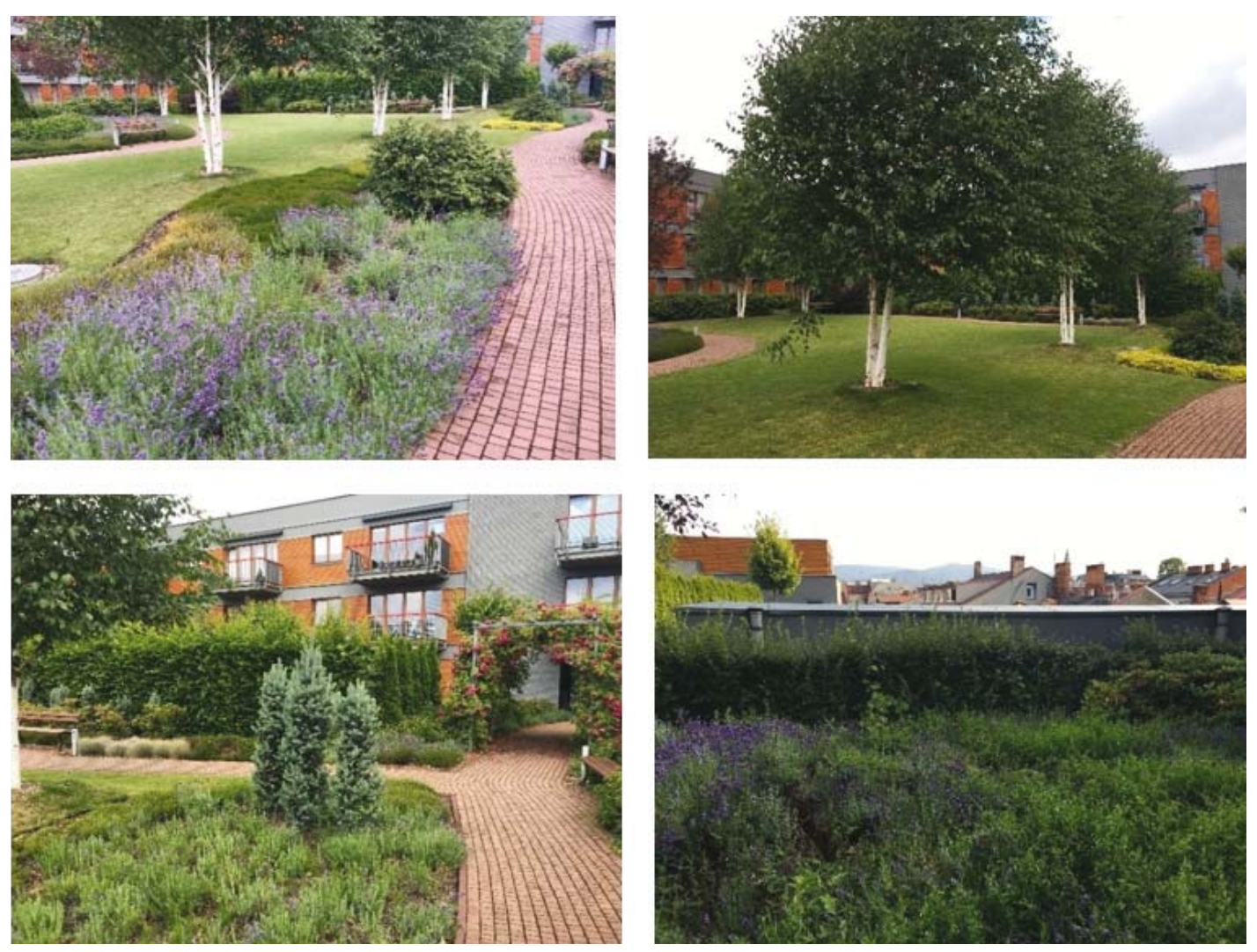

Fig. 2. Intensive roof, shopping center Sfera II, Bielsko-Biała, Poland (photo by A. Boas Berg, 2017)

In the years 2014-2020 Poland should receive 82.5 billion EUR from the EU budget for cohesion policy. Over 27.4 billion EUR, which makes about 115.6 billion PLN, should be allocated to the Operational Program Infrastructure and Environment 2014-2020. It will finance projects in the energy sector, primarily in the areas of: renewable energy sources, energy efficiency and energy security. To reduce the emissivity of the economy and 
Boas Berg, A., Radziemska, M., Adamcová, D., Vaverková, M.D. (2017). Green roofs as an alternative solution to reduced green surface area in highly urbanized cities of the European Union - the study case of the Netherlands. Acta Sci. Pol. Architectura, 16 (4), 59-70. doi: 10.22630/ASPA.2017.16.4.06.

to protect the environment, including adaptation to climate change are the main priorities in this field (European Funds Portal, n.d.).

Projects in the field of creating and renewing the living walls are to be organized. In particular, noise-isolating and greening of existing building walls (provided the historic urban landscape is preserved and no traffic or pedestrian visibility is obstructed). Projects of green roofs on existing buildings, along with the necessary green infrastructure are being planned - including the ones with (in justified cases) the construction of a new roof truss.

\section{SOLUTIONS USED ON GREEN ROOFS}

Green roofs on which flowers and plants are planted to help maintaining the bee and butterfly's population are more and more popular in the Netherlands. One of the green roof manufacturers in the Netherlands is Sempergreen BV. The company has nurseries for plant breeding in Poland, the Netherlands, Spain, North America, Colombia and China. As a breeder, the company has been creating green roofs since 1996 and living walls since 1998. The company's goal is also to increase an interest in green roofs in Central and Eastern Europe. The company recently increased its production by opening new horticulture in Poland, near the German border. Horticulture covers 50 ha and it serves as an extension to the existing one in the center of the Netherlands with an area of 160 ha. The largest part of Polish horticulture has been designed to produce various green covers for roofs. What is more, 6 ha of the horticulture is occupied by seedlings that are later used for the production of green ground covers (Sempergreen BV, 2017). The system structures of the chosen green roofs are presented in Tables 1-5.

Table 1. Light green roof $0-15^{\circ}$ (Sempergreen BV, 2017)

\begin{tabular}{ll}
\hline System structures & Specification \\
\hline Characteristics & gradient: $0-15^{\circ}$, thickness including sedum: $61-70 \mathrm{~mm}$; saturated weight: $40-45 \mathrm{~kg} \cdot \mathrm{m}^{-2}$ \\
\hline Sedum-mixed mat & $\begin{array}{l}\text { thickness: } 30 \mathrm{~mm} \text {; precultivated mixed-type mat consists of } 10 \text { to } 12 \text { different types of sedum, on delivery } \\
\text { plants cover } 95 \% \text { of the mat }\end{array}$ \\
\hline Substrate & $\begin{array}{l}\text { thickness: } 20 \mathrm{~mm} \text {; the substrate is used to create light green roof made of long mineral wool fibers, it is an } \\
\text { excellent base for plant growth, it also ensures good water absorption and strength }\end{array}$ \\
\hline Drainage including filterfleece & $\begin{array}{l}\text { thickness: } 11-20 \mathrm{~mm} \text {; thickness of the drainage layer will depend on the structure of the roof, the climate } \\
\text { and the required storage water capacity }\end{array}$ \\
\hline
\end{tabular}

Layout

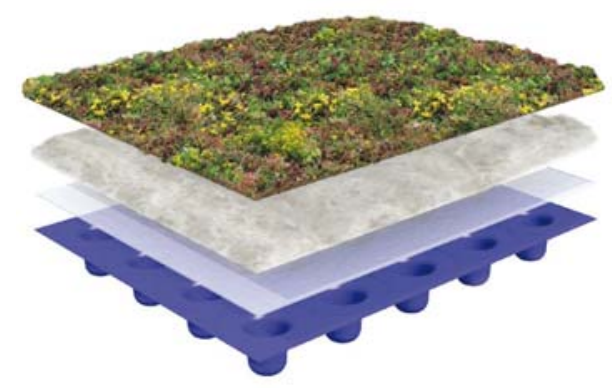


Boas Berg, A., Radziemska, M., Adamcová, D., Vaverková, M.D. (2017). Green roofs as an alternative solution to reduced green surface area in highly urbanized cities of the European Union - the study case of the Netherlands. Acta Sci. Pol. Architectura, 16 (4), 59-70. doi: 10.22630/ASPA.2017.16.4.06.

Table 2. Flat roofs $0-5^{\circ}$ water retaining (Sempergreen BV, 2017)

\begin{tabular}{ll}
\hline System structure & Specification \\
\hline Characteristics & gradient: $0-5^{\circ}$; thickness including sedum: $80-110 \mathrm{~mm}$; saturated weight: $80-85 \mathrm{~kg} \cdot \mathrm{m}^{-2}$ \\
\hline $\begin{array}{l}\text { Sedum-mixed mat } \\
\text { thickness: } 30 \mathrm{~mm} \text {; precultivated mixed-type T mat is a mixture of } 10 \text { to } 12 \text { varieties of sedum, on } \\
\text { delivery the plant coverage is at least } 95 \%\end{array}$ \\
$\begin{array}{ll}\text { Exstensive roof } \\
\text { garden substrate }\end{array}$ & $\begin{array}{l}\text { thickness: } 40 \mathrm{~mm} \text {; extensive substrate consists of lava, pumice and compost and it is being produced } \\
\text { according to FLL guidelines }\end{array}$ \\
\hline $\begin{array}{l}\text { Drainage including } \\
\text { filterfleece }\end{array}$ & $\begin{array}{l}\text { thickness: } 10-40 \mathrm{~mm} \text {; depending on the climate, the thickness of the drainage layer depends on the roof } \\
\text { structure and the desired water storage capacity }\end{array}$ \\
\hline
\end{tabular}

Layout

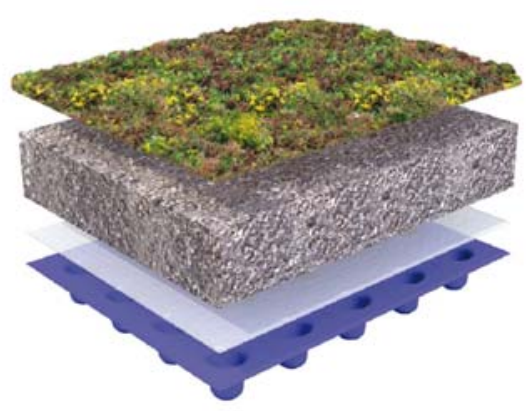

Table 3. Shallow pitched roof $5-25^{\circ}$ water retaining (Sempergreen BV, 2017)

\begin{tabular}{ll}
\hline System structure & Specification \\
\hline Characteristics & gradient: $5-25^{\circ}$; thickness including sedum: $90-120 \mathrm{~mm}$; saturated weight: $95-100 \mathrm{~kg} \cdot \mathrm{m}^{-2}$ \\
\hline Sedum-mixed mat & $\begin{array}{l}\text { thickness: } 30 \mathrm{~mm} \text {; precultivated mixed-type T mat is a mixture of } 10 \text { to } 12 \text { varieties of sedum, } \\
\text { on delivery the plant coverage is at least } 95 \%\end{array}$ \\
\hline Extensive roof garden substrate & $\begin{array}{l}\text { thickness: } 40 \mathrm{~mm} \text {; extensive substrate consists of lava, pumice and compost and it is being } \\
\text { produced according to FLL guidelines }\end{array}$ \\
\hline Drainage including filterfleece & $\begin{array}{l}\text { thickness: } 10-40 \mathrm{~mm} \text {; depending on the climate, the thickness of the drainage layer depends } \\
\text { on the roof structure and the desired water storage capacity }\end{array}$ \\
\hline
\end{tabular}

Layout

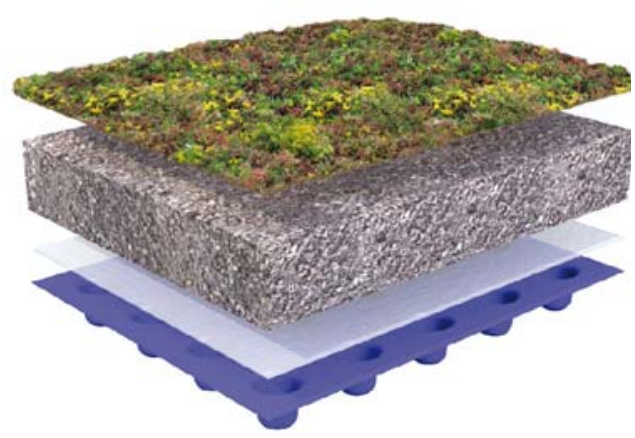


Boas Berg, A., Radziemska, M., Adamcová, D., Vaverková, M.D. (2017). Green roofs as an alternative solution to reduced green surface area in highly urbanized cities of the European Union - the study case of the Netherlands. Acta Sci. Pol. Architectura, 16 (4), 59-70. doi: 10.22630/ASPA.2017.16.4.06.

Table 4. Steeply pitched roof $25-45^{\circ}$ water retaining (Sempergreen BV, 2017)

\begin{tabular}{|c|c|}
\hline System structure & Specification \\
\hline Characteristics & gradient $25-45^{\circ}$; thickness including sedum: $90 \mathrm{~mm}$; saturated weight: $100-105 \mathrm{~kg} \cdot \mathrm{m}^{-2}$ \\
\hline Sedum-mixed mat & $\begin{array}{l}\text { thickness: } 30 \mathrm{~mm} \text {; precultivated mixed-type T mat consists of } 10 \text { to } 12 \text { sedum types, the } \\
\text { basis of this green cover is the plastic reinforcement top and bottom which make the blanket } \\
\text { suitable for (steeply) pitched applications; on delivery the plant coverage is at least } 95 \%\end{array}$ \\
\hline Extensive roof garden substrate & $\begin{array}{l}\text { thickness: } 50 \mathrm{~mm} \text {; extensive substrate consists of lava, pumic and compost - it was } \\
\text { produced according to FLL guidelines }\end{array}$ \\
\hline Substrate holder & $\begin{array}{l}\text { the holder is a plastic grid made of recycled LDPE/HDPE; it prevents the substrate from } \\
\text { slipping of the mat }\end{array}$ \\
\hline Water retaining fleece & $\begin{array}{l}\text { thickness: } 10 \mathrm{~mm} \text {; the fleece is a mat made of recycled fabric; the mat retains water and is } \\
\text { also used to protect the roof; the mat functions as a water storage for a vegetation blanket }\end{array}$ \\
\hline Layout & \\
\hline
\end{tabular}

Table 5. Biodiverse green roof (Sempergreen BV, 2017)

Specification

a biodiverse mat and a mat attracting bees and butterflies

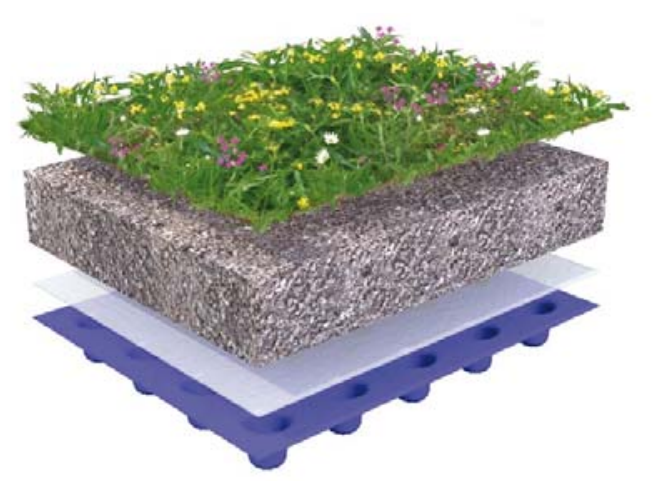

A biodiverse mat and a mat attracting bees and butterflies

(sedum with wildflower blanket and shadow blanket)

Biodiverse roof garden substrate $150 \mathrm{~mm}$

Drainage including filterfleece 11-20 mm

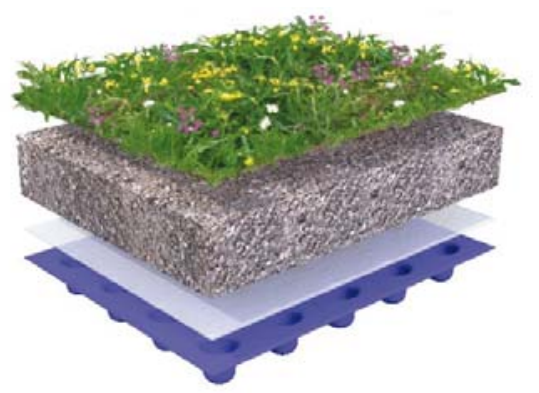


Boas Berg, A., Radziemska, M., Adamcová, D., Vaverková, M.D. (2017). Green roofs as an alternative solution to reduced green surface area in highly urbanized cities of the European Union - the study case of the Netherlands. Acta Sci. Pol. Architectura, 16 (4), 59-70. doi: 10.22630/ASPA.2017.16.4.06.

The Dutch company, Sempergreen BV, offers, extensive roofs (Fig. 3 and Fig. 4), biodiverse and butterfly and bee-attracting ones, as well as living walls.
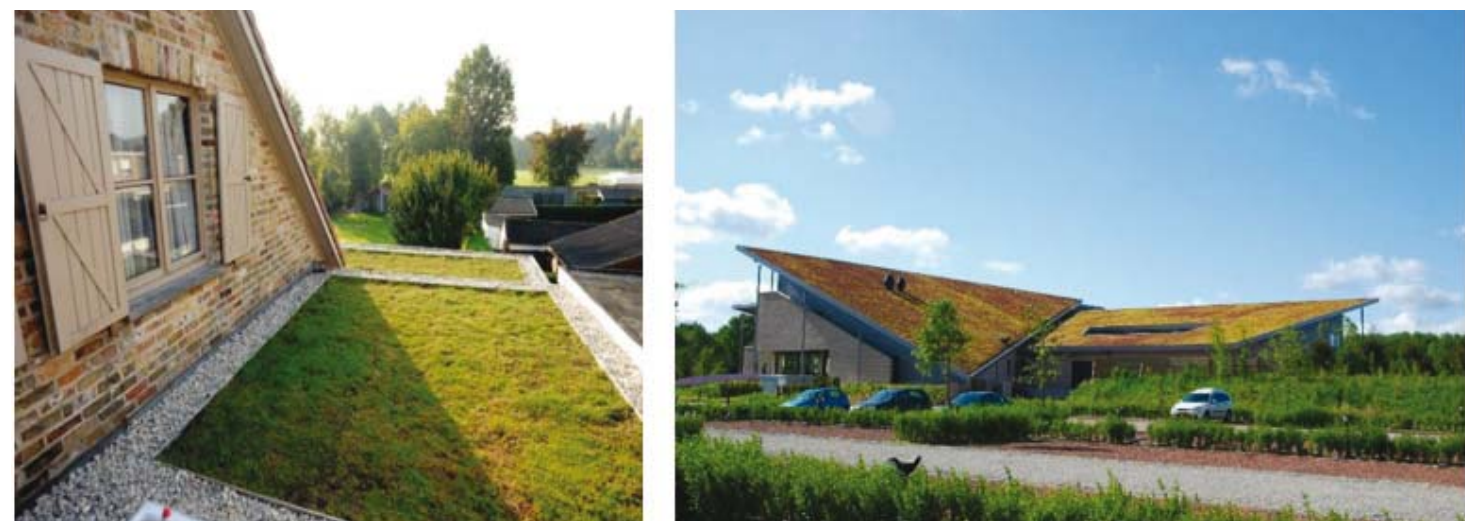

Fig. 3. Extensive roof, the Netherlands (Sempergreen BV, 2017)
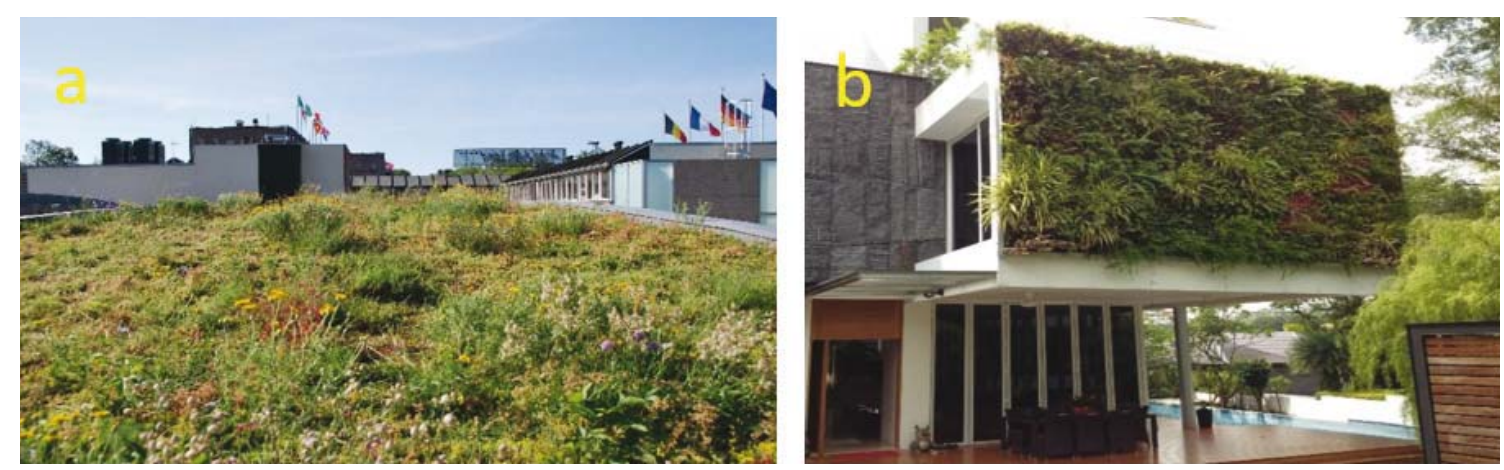

Fig. 4. Biodiverse green roof : $\mathrm{a}$ - an office building, the Netherlands; $\mathrm{b}$ - a living wall of a private residence, the Netherlands (Sempergreen BV, 2017)

The Erasmus MC Sophia Children's Hospital in Rotterdam received a subsidy for building a 5,000 $\mathrm{m}^{2}$ green roof area (Fig. 5).
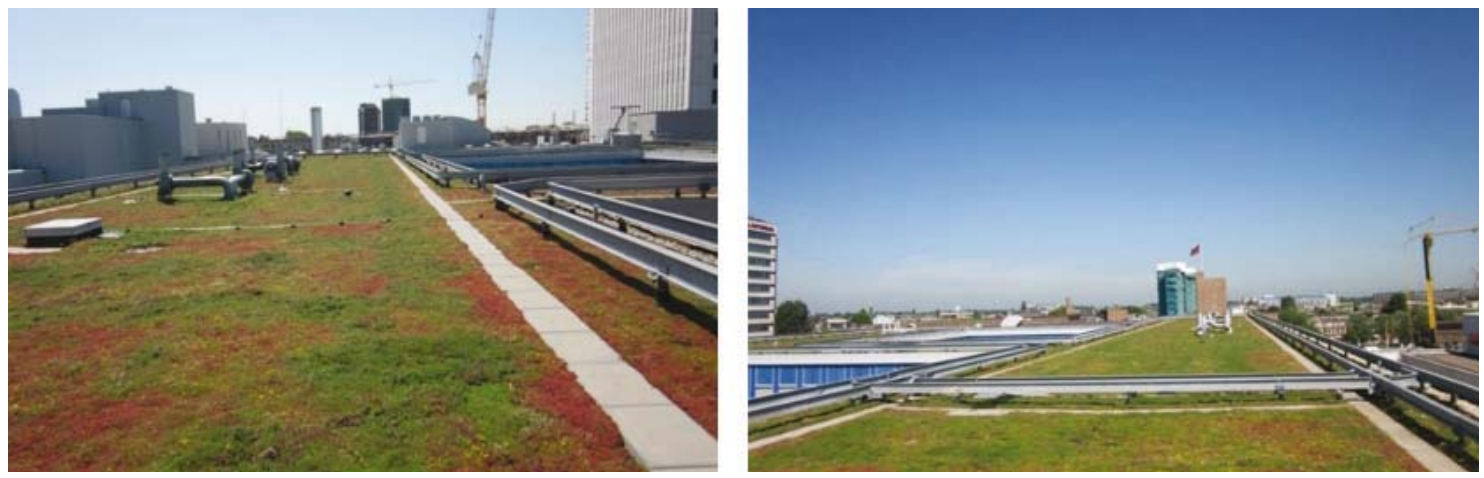

Fig. 5. The roof of Erasmus MC Sophia Children's Hospital in Rotterdam (http://www.binder.nl/daktuin-emcsophia-dak) 


\section{CONCLUSIONS}

According to the World Health Organization (WHO), the minimum area of green areas should be $50 \mathrm{~m}^{2}$ per urban agglomeration resident (http://www.who.int/en). However, the reality is different in many European cities. Urban areas do not provide adequate space for green areas. The perfect solution would be the green roof. Green roofs count as biologically active areas - the Polish legislator provides for such types of green areas to convert $50 \%$ of the area, provided that it is at least $10 \mathrm{~m}^{2}$. The green roof is not only visually appealing, but also offers a variety of other environmentally friendly and comfortable amenities; such as relieving the city sewer through rainwater retention, temperature control, sound isolation, air purification and biodiversity. The green roofs can be covered with a special vegetation, sedum, that retains water. Sedum belongs to the family Crassulaceae, and is a type of plants called succulents (Sempergreen BV, 2017). Other green plants can also be grown on green roofs: herbs and wildflowers, or other vegetation in a manner attractive to bees and butterflies. Thus, green roofs with flowers can contribute to preserving the bees population.

In European society, the awareness of the importance of green areas and sustainable environments is constantly growing. With the awareness of living in harmony with nature, there is also a growing demand for green roofs. The roof offers a number of ecological but also financial benefits (some European cities use subsidies for these investments, while green roofs reduce the use of expensive energy to heat or cool houses). Green roofs also contribute to a better and cleaner living space.

\section{Acknowledgment}

This study was supported by the firm Sempergreen BV. We would like to express our great appreciation to the management of the company. Namely, we are very grateful to Corné van Garderen and his colleagues for their assistance and their willingness to provide their time so generously.

\section{REFERENCES}

Adger, N., Barnett, J., Brown, K. \& Marsh, N. (2013). Cultural dimensions of climate change impact and adaptation. Nature Climate Change, 3, 112-117.

Arge, S.V. (2000). Vikings in the Faeroe Islands. In W. Fitzhugh, E.I. Ward (Eds), Vikings: The north Atlantic saga (pp. 154-156). Washington, DC: Smithsonian Institution Press.

Bartkiewicz, M. (2017). Pomyst na dom: Jak zielony dach może wptywać na samopoczucie czlowieka? Pomyst na dom: jak zielony dach może wptywać na samopoczucie czlowieka? Retrieved from: http://www.pomyslnadom.pl/dachy_i rynny/jak_zielony_dach_moze_wplywac_na_samopoczucie_czlowieka_d32734.html.

Baryła, A., Siedlicka, B. \& Karczmarczyk, A. (2015). Zmiany temperatury różnych form użytkowania zielonego dachu. Infrastructure and Ecology of Rural Areas, 04 (1), 1081-1088.

Behrens-Abouseif, D. (1989). Islamic architecture in Cairo: An introduction. Cairo, Egypt: American University in Cairo Press.

Berardi, U., Hoseini, G., Ghaffarian, A. \& Hoseini, A. (2014). State-of-the-art analysis of the environmental benefits of green roofs. Applied Energy, 115, 411-428.

Bradbear, N. (2009). Bees and Their Role in Forest Livelihoods: a Guide to the Services provided by Bees and the Sustainable Harvesting, Processing and Marketing of Their Products, Non-Wood Forest Products. Vol. 19. Rome: Food and Agriculture Organization of the United Nations (FAO).

Brudermann, T. \& Sangkakool, T. (2017). Green roofs in temperate climate cities in Europe - An analysis of key decision factors. Urban Forestry \& Urban Greening, 21, 224-234.

Chen, C-F. (2013). Performance evaluation and development strategies for green roofs in Taiwan: a review. Ecological Engineering, 52, 51-58.

Condello, A. (2014). The architecture of luxury. Ashgate, Farnham, UK. Gemeente Apeldoorn. 
Boas Berg, A., Radziemska, M., Adamcová, D., Vaverková, M.D. (2017). Green roofs as an alternative solution to reduced green surface area in highly urbanized cities of the European Union - the study case of the Netherlands. Acta Sci. Pol. Architectura, 16 (4), 59-70. doi: 10.22630/ASPA.2017.16.4.06.

European Funds Portal (n.d.): Operational Programme Infrastructure and Environment 2014-2020. Retrieved from: https://www.funduszeeuropejskie.gov.pl/en/site/learn-more-about-european-funds/look-through-the-documents/operational-programme-infrastructure-and-environment-20142020.

Grixti, J. C., Wong, L. T., Cameron, S. A. \& Favret, C. (2009). Decline of bumble bees (Bombus) in the North American Midwest. Biological Conservation, 142 (1), 75-84.

Gwak, J. H., Lee, B. K., Lee, W. K. \& Sohn S. Y. (2017). Optimal location selection for the installation of urban green roofs considering honeybee habitats along with socio-economic and environmental effects. Journal of Environmental Management, 189, 125-133.

Francesch-Huidobro, M., Dabrowski, M., Tai, Y., Chan, F. \& Stead, D. (2017). Governance challenges of flood-prone delta cities: Integrating flood risk management and climate change in spatial planning. Progress in Plant Protection, $114,1-27$.

Jim, C. Y. (2017). Green roof evolution through exemplars: Germinal prototypes to modern variants. Sustainable Cities and Society. https://doi.org/10.1016/j.scs.2017.08.001.

Klein, A. M., Vaissiere, B. E., Cane, J. H., Steffan-Dewenter, I., Cunningham, S. A., Kremen, C. \& Tscharntke, T. (2007). Importance of pollinators in changing landscapes for world crops. Proceedings of the Royal Society of London B: Biological Sciences, 274 (1608). doi: 10.1098/rspb.2006.3721.

Kluser, S. \& Peduzzi P. (2007). Global Pollinator Decline: a Literature Review. Geneva, Switzerland: United Nations Environment Programme/Global Resource Information Database.

Kożuchowski, P. \& Piątek-Kożuchowska, E. (2009). Dach zielony - skuteczna metoda zabezpieczenia pokryć hydroizolacyjnych. Inżynier Budownictwa, 5, 65-67.

Locatelli, L., Mark, O., Mikkelsen, P. S., Arnbjerg-Nielsen, K., Bergen Jensen, M. \& Binning P. J. (2014). Modelling of green roof hydrological performance for urban drainage applications. Journal of Hydrology, 519 (Part D), 3237-3248.

Maclvor, J. S. \& Ksiazek, K. (2015). Invertebrates on green roofs. Green Roof Ecosystems, 223, 333-355.

Mitsch, W. J. (2012). What is ecological engineering? Ecological Engineering, 45, 5-12.

Molineux, C. J., Fentiman, C. H. \& Gange, A. C. (2009). Characterising alternative recycled waste materials for use as green roof growing media in the UK. Ecological Engineering, 35 (10), 1507-1513.

Murray, T. E. ,Kuhlmann, M. \& Potts, S. G. (2009). Conservation ecology of bees: populations, species and communities. Apidologie, 40 (3), 211-236.

Petrović, N., Bojović, N. \& Petrović, J. (2016). Appraisal of urbanization and traffic on environmental quality. Journal of $\mathrm{CO}_{2}$ Utilization, 16, 428-430.

Quistberg, R. D., Bichier, P. \& Philpott, S. M. (2016). Landscape and local correlates of bee Abundance and species richness in urban gardens. Environmental Entomology, 45 (3), 592-601.

Rataj, A. (2016). Morizon: Zielone dachy - niesamowite domy z krajów skandynawskich. Retrieved from: https://www. morizon.pl/blog/zielone-dachy-niesamowite-domy-z-krajow-skandynawskich.

Semaan, M. \& Pearce, A. (2016). Assessment of the Gains and Benefits of Green Roofs in Different Climates. Procedia Engineering, 145, 333-339.

Sempergreen BV (2017). Solutions: Green roof, Living wall, Green ground cover. Sempergreen: Naturally. The Netherlands. Retrieved from: https://www.sempergreen.com/en/solutions.

Shaneyfelt, K. M., Anderson, A. R., Kumar, P. F. \& Hunt, W. F. (2017). Air quality considerations for stormwater green street design. Environmental Pollution, 231, Part 1, 768-778.

Sokołowska, B. \& Krajczyński, M. (2004). Stropodachy: Projektowanie i wykonawstwo. Koszalin: Wydawnictwo Politechniki Koszalińskiej.

Tonietto, R., Fant, J., Ascher, J., Ellis, K. \& Larkin, D. (2011). A comparison of bee communities of Chicago green roofs, parks and prairies. Landscape and Urban Planning, 103 (1), 102-108.

Vijayaraghavan, K. (2016). Green roofs: A critical review on the role of components, benefits, limitations and trends. Renewable and Sustainable Energy Reviews, 57, 740-752.

Winfree, R., Aguilar, R., Vázquez, D. P., LeBuhn G. \& Aizen, M. A. (2009). A meta-analysis of bees' responses to anthropogenic disturbance. Ecology, 90 (8), 2068-2076. 
Boas Berg, A., Radziemska, M., Adamcová, D., Vaverková, M.D. (2017). Green roofs as an alternative solution to reduced green surface area in highly urbanized cities of the European Union - the study case of the Netherlands. Acta Sci. Pol. Architectura, 16 (4), 59-70. doi: 10.22630/ASPA.2017.16.4.06.

Yousefpour, R., Didion, M., Jacobsen, J. B., Meilby, H., Hengeveld, G. H., Schelhaas, M-J. \& Thorsen, B. J. (2015). Modelling of adaptation to climate change and decision-makers behaviours for the Veluwe forest area in the Netherlands. Forest Policy Economics, 54, 1-10.

\section{ZIELONE DACHY ALTERNATYWA NA REDUKCJĘ TERENÓW ZIELENI W SILNIE ZURBANIZOWANYCH MIASTACH UNII EUROPEJSKIEJ NA PRZYKŁADZIE HOLANDII}

\section{STRESZCZENIE}

Autorzy przedstawili informacje na temat zielonych dachów w krajach Unii Europejskiej (UE) na przykładzie doświadczeń firm konstrukcyjnych w Holandii, a także zbadali sytuacje w Polsce. Wybór tych krajów nie był przypadkowy, ale związany z tym, że holenderscy planiści przestrzenni są zainteresowani współpraca i dzieleniem się swoim doświadczeniem z polskimi specjalistami. W pracy przedstawiono również krótką historię stosowania zielonych dachów (m.in. w Europie). W kwestiach technicznych zaczerpnięto informacje od firm holenderskich. Autorzy przedstawili zalety zielonych dachów oraz zasadność finansowania tych projektów przez UE. Zielone dachy odciążają systemy kanalizacji w miastach, przeciwdziałają podtopieniom po burzy i ulewach, zmniejszają negatywne skutki miejskich wysp ciepła oraz przeciwdziałają emisji $\mathrm{CO}_{2}$. Zielone dachy mogą być rozwiązaniem problemów na terenach narażonych na emisje szkodliwych gazów. Bardzo istotną rzeczą jest to, że dachy te stanowią izolację termiczną, przez co w budynkach zużywane są mniejsze ilości energii na ogrzewanie zimą i klimatyzację latem (efektywność energetyczna).

Słowa kluczowe: historia zielonych dachów, zielone dachy, miejskie tereny zieleni, architektura, ogrody na dachach, przykłady ogrodów na dachach 